\title{
FTO POLYMORPHISM AND PHYSICAL FITNESS IN OBESE SCHOOLCHILDREN AFTER AN INTERVENTION PROGRAM
}

\author{
POLIMORFISMO NO GENE FTO EAPTIDÃO FÍSICA EM ESCOLARES OBESOS APÓS PROGRAMA \\ DE INTERVENÇÃO
}

I A

Original Article

ARTIGo ORIGINAL

Artículo Original

\author{
POLIMORFISMO EN EL GENEFTO Y APTITUD FÍSICA EN ESCOLARES OBESOS DESPUÉS \\ DEPROGRAMA DE INTERVENCIÓN
}

\author{
Greice Graziela Moraes' \\ (Pharmaceutical) \\ Cézane Priscila Reuter ${ }^{2}$ \\ (Pharmaceutical) \\ Elisa Inês Klinger \\ (Pharmaceutical) \\ Daniel Prá4 (Biologist) \\ Andréia Rosane de Moura Valim ${ }^{3}$ \\ (Pharmaceutical) \\ Miria Suzana Burgos ${ }^{4}$ \\ (Physical Education Professional)
}

1. Universidade de Santa Cruz do Sul, Programa de Pós-Graduação em Promoção da Saúde, Santa Cruz do Sul, RS, Brazil.

2. Universidade de Santa Cruz do

Sul, Departamento de Educação

Física e Saúde. Santa Cruz do Sul,

RS, Brazil.

3. Universidade de Santa Cruz do

Sul, Departamento de Biologia

e Farmácia. Programa de Pós-

Graduação em Promoção da Saúde,

Santa Cruz do Sul, RS, Brazil.

4. Universidade de Santa Cruz do

Sul, Departamento de Educação

Física e Saúde. Programa de Pós-

Graduação em Promoção da Saúde,

Santa Cruz do Sul, RS, Brazil.

\section{Correspondence:}

Miria Suzana Burgos

Universidade de Santa Cruz do Sul,

Programa de Pós-Gradução em

Promoção da Saúde.

Av. Independência, 2293 -

Bloco 42, sala 4206, Santa Cruz do

Sul, RS, Brasil. 96815-900.

mburgos@unisc.br

\begin{abstract}
Introduction: Recent studies have shown that the association of FTO rs9939609 gene polymorphism with obesity depends on the level of the individual's physical activity. However, there are some studies that evaluated physical fitness, health, and motor performance in relation to the rs $9939609 \mathrm{FTO}$ gene polymorphism. Objective:To evaluate how the rs $9939609 \mathrm{FTO}$ gene polymorphism affects the results of physical fitness tests related to health and athletic performance in schoolchildren after 4 months of intervention of physical exercise. Method: The rs 9939609 FTO gene polymorphism was genotyped in a total of 36 schoolchildren from southern Brazil, aged 8 to 16 years. Body mass index (BMI), health-related physical fitness (cardiorespiratory fitness, abdominal strength/endurance, and flexibility) and motor performance (upper and lower limb strength, agility, and speed) were evaluated. The intervention included exercise strategies based on Physical Education, healthy eating, and oral and postural care. Results: In the experimental group, after the intervention, significant differences were noted in individuals with the $\Pi$ genotype. These individuals showed improvements in abdominal strength ( $p=0.025)$, lower limb strength $(p=0.037)$ and agility ( $p=0.021)$. For individuals with the AA/AT genotype, improvements in flexibility $(p=0.026)$, abdominal strength $(p=0.002)$, upper limb strength $(p=0.008)$ and lower limb strength $(p=0.001)$ were observed. However, these differences were not statistically significant when comparing the TT and AT/AA genotypes. Conclusions: The experimental group showed improvements in abdominal strength, lower limb strength, and speed. Yet, individuals with different genotypes (AA/AT and TT) for polymorphism rs9939609 exhibited similar values for indicators of physical fitness, health, and motor performance. Level of Evidence ll; Lesser quality RCT.
\end{abstract}

Keywords: Genetics; Fat mass and obesity associated protein; Obesity; Exercise; Motor activity.

\section{RESUMO}

Introdução: Estudos recentes demonstraram que a associação do polimorfismo do geneFTO rs9939609 e a obesidade dependem do nivel de atividade fisica de um individuo. No entanto, existem alguns estudos que avaliaram a aptidão física, a saúde e o desempenho motor com relação ao polimorfismo rs9939609 do gene FTO. Objetivo: Avaliar como o polimorfismo rs 9939609 do gene FTO afeta os resultados dos testes de aptidão física relacionados com a saúde e o desempenho atlético em escolares após 4 meses de intervenção com exercícios físicos. Método: O polimorfismo rs 9939609 do gene FTO foi genotipado em um total de 36 escolares do sul do Brasil, com idades entre 8 e 16 anos. O índice de massa corporal (IMC), a aptidão física relacionada com a saúde (aptidão cardiorrespiratória, força abdominal/resistência eflexibilidade) e desempenho motor (força de membros superiores e inferiores, agilidade e velocidade) foram avaliados. A intervenção teve como base estratégias de exercícios da Educação Física e alimentação saudável, além de cuidados bucais e posturais. Resultados: No grupo experimental, após a intervenção, observaram-se diferenças significativas em indivíduos com o genótipo TT. Esses indivíduos apresentaram melhorias na força abdominal ( $p=0,025)$, força dos membros inferiores ( $p$ $=0,037)$ e agilidade $(p=0,021)$. Para os indivíduos com o genótipo AA AT, foram observadas melhorias na flexibilidade $(p=0,026)$, força abdominal $(p=0,002)$, força dos membros superiores $(p=0,008)$ e força dos membros inferiores $(p=0,001)$. No entanto, essas diferenças não foram estatisticamente significantes ao se comparar os genótipos TT eAT/AA. Conclusões: O grupo experimental apresentou melhorias na força abdominal, força dos membros inferiores evelocidade. Contudo, individuos com diferentes genótipos (AA/AT e TT) para o polimorfismo rs9939609 exibiram valores semelhantes para indicadores de aptidão física, saúde e desempenho motor. Nível de Evidência ll, ECRC de menor qualidade.

Descritores: Genética; Proteína associada à massa gorda e obesidade; Obesidade; Exercício; Atividade motora.

\section{RESUMEN}

Introducción: Estudios recientes han demostrado quela asociación del polimorfismo del gen FTO rs9939609y la obesidad dependen del nivel de actividad física de um individuo. Sin embargo, existen algunos estudios que evaluaron la aptitud física, la salud y el rendimiento motor con relación al polimorfismo rs9939609 del gen FTO. Objetivo: Evaluar cómo el polimorfismo rs9939609 del gen FTO afecta los resultados de las pruebas de aptitud física relacionadas con la salud y el desempeño atlético en escolares después de 4 meses de intervención con ejercicios físicos. Método: El polimorfismo rs9939609 del gen FTO fue genotipado en un total de 36 escolares del sur de Brasil, con edades entre 8 y 16 años. El índice de masa corporal (IMC), la aptitud 
fisica relacionada con la salud (aptitud cardiorrespiratoria, fuerza abdominal/resistencia y flexibilidad) y rendimiento motor (fuerza de las extremidades superiores e inferiores, agilidad y velocidad) fueron evaluados. La intervención tuvo como base estrategias de ejercicios de Educación Física y alimentación saludable, además de cuidados bucales y posturales. Resultados: En el grupo experimental, después de la intervención, se observaron diferencias significativas en individuos con el genotipo $\pi$ T. Estos individuos presentaron mejoras en la fuerza abdominal ( $p=0,025)$, fuerza de las extremidades inferiores $(p=0,037)$ y agilidad ( $p=0,021$ ). Para las personas con el genotipo AANAT, se observaron mejoras en la flexibilidad ( $p=0,026)$, fuerza abdominal ( $p=0,002)$, fuerza de las extremidades superiores $(p=0,008)$ y fuerza de las extremidades inferiores $(p=0,001)$. Sin embargo, estas diferencias no fueron estadísticamente significativas al comparar los genotipos TTy AT/AA. Conclusiones: El grupo experimental presentó mejoras en la fuerza abdominal, fuerza de las extremidades inferiores y velocidad. No obstante, individuos con diferentes genotipos (AAATy TT) para el polimorfismo rs9939609 mostraron valores similares para indicadores de aptitud física, salud y rendimiento motor. Nivel de Evidencia ll; ECRC de menor calidad.

Descriptores: Genética; Proteína asociada a la masa grasa y la obesidad; Obesidad; Ejercicio; Actividad motora.

\section{INTRODUCTION}

Obesity is a public health problem that results in increased morbidity and mortality associated with cardiovascular disease, type II diabetes and renal disease. ${ }^{1}$ The pathogenesis of obesity is influenced by interactions between genetics and the environment. ${ }^{2}$ Previous studies have suggested that the rs9939609 polymorphism in the fat mass and obesity-associated FTO gene is associated with adiposity and obesity in individuals possessing the AA genotype. ${ }^{3,4}$ The FTO gene is highly expressed in the hypothalamus and is known to regulate energy homeostasis. ${ }^{5}$

The FTO gene is expressed in the cell nuclei of almost all human tissues. ${ }^{6}$ High levels of FTO expression are found in the brain, particularly in the arcuate nucleus of the hypothalamus. ${ }^{7}$ The possible role of this gene in energy homeostasis is supported by studies in humans and mice that have shown that FTO mRNA expression is regulated by food consumption. ${ }^{8}$

Although a growing number of studies have shown that the FTO gene is associated with obesity, recent studies have demonstrated that this association depends on an individual's level of physical activity. An intervention study conducted on European and non-European populations was the first to confirm a significant association between the rs9939609 FTO gene polymorphism and physical activity level ${ }^{4}$. In another intervention directed by Mitchell et al., ${ }^{9} 464$ postmenopausal women were genotyped for the rs8050136 FTO gene polymorphism. In the referenced study, after a 6-month physical activity intervention, the results of a cardiorespiratory fitness test were similar between individuals with both genotypes (AA and CC) of this polymorphism.

A key marker of health in childhood and adolescence is physical fitness. ${ }^{10,11}$ The main components of health-related physical fitness are cardiorespiratory fitness, flexibility and abdominal strength. ${ }^{12}$ Engine performance is another common evaluation criterion, and previous studies have indicated that excess weight in young people reduces flexibility, motor performance, agility, balance, and lower and upper limb strength. ${ }^{13-15}$

Thus, the current study aimed to verify that individuals possessing obesity-risk genotypes (AA and AT) of the rs9939609 FTO gene polymorphism respond differently to physical fitness and produce different results on tests related to health and motor performance compared to carriers of the TT genotype following an interdisciplinary intervention program.

\section{METHODS}

The current study was a pilot multidisciplinary intervention study conducted at three schools (one for the experimental group and two for the control group) in a rural region of the municipality of Santa Cruz do Sul, RS. A total of 36 students were enrolled in the study: 17 were placed in the control group and 19 in the intervention group. All students were aged between 8 and 16 years and were either overweight or obese.

An intervention program was developed through a multidisciplinary team. The intervention included exercise strategies based on physical education, healthy eating, and oral and postural care. The intervention syllabus covered a period of four months and was conducted three times per week.

The experimental group was submitted to weekly meetings that lasted for one hour and 30 minutes. Each of these meetings included a 10-minute warm-up, 50 minutes of aerobic exercise, 20 minutes of exercise using entertaining props (e.g., jump rope, trampoline circuit footprints and pick-ups) and a 10 minute presentation of guidelines related to postural re-education and nutritional counseling/oral hygiene.

To calculate the sample size, we used the $\mathrm{G}^{*}$ Power ${ }^{16}$ program with a test power of 0.8 , an effect of 0.30 and a $95 \%$ significance level. The results suggested that at least 12 subjects were needed for the experimental group and 12 subjects for the control group.

Informed consent was obtained from all study participants and their parents prior to the start of the intervention. The study was conducted in accordance with resolution 466 from the National Council of Health Ministry of Health recommendations from 12 December 2012 regarding ethical issues related to research on human subjects. The study was approved by the Research Ethics Committee of our institution (advice number 357 403/2013).

A pre-assessment was conducted prior to the intervention, and another assessment was conducted after the completion of the intervention. During these assessments, blood was collected for later analysis; anthropometric measurements were made; and physical fitness, health and motor performance were assessed using tests. The same tests were given to the control and intervention groups.

We used a salting out protocol to extract DNA ${ }^{17}$ from $500 \mu \mathrm{L}$ samples of peripheral blood leukocytes. After extraction, the DNA was resuspended in water for further analysis. We used real-time polymerase chain reaction (PCR) to genotype the DNA; PCR was performed at the Laboratory of Genetics and Biotechnology at the University of Santa Cruz do Sul (UNISC). A/T genotyping was performed using TaqMan probes (Applied Biosystems, Foster City, CA, USA) on StepOnePlus equipment (Applied Biosystems, Foster City, CA, USA) according to the manufacturer's instructions.

To calculate BMI, we used a ratio of body weight $(\mathrm{kg})$ to height squared $\left(\mathrm{m}^{2}\right)$; the results were expressed as $\mathrm{kg} / \mathrm{m}^{2}$. BMI was classified according to the percentile curves produced by the Centers for Disease Control and Prevention/National Center for Health Statistics ${ }^{18}$ according to gender and age. The following classifications were used: underweight 
$(<\mathrm{p} 5)$, normal weight ( $\geq \mathrm{p} 5$ and $<\mathrm{p} 85$ ), overweight $(\geq \mathrm{p} 85$ and $<\mathrm{p} 95)$ and obese ( $\geq$ p95).

Physical fitness, health and motor performance were tested following standardized methods published by the Sport Brazil Project (PROESP-BR). ${ }^{19}$ Three tests were used to evaluate physical fitness and health; these included assessments of cardiorespiratory fitness (running test/6-minute walk test results, given in meters), flexibility (sit and reach test results, given in centimeters) and abdominal strength (number of abdominal crunches performed in one minute).

Four tests were used to evaluate motor performance; these included assessments of upper limb strength (medicine ball throwing test results, recorded as distance in meters), lower limb strength (horizontal jump test results, recorded as distance in meters), agility (square test results, recorded in seconds) and speed (20-meter-run results, recorded in seconds).

SPSS version 23.0 (IBM, Armonk, USA) was used for statistical analysis. The normality of data distributions was first evaluated using the Shapiro-Wilk test. Subsequently, for variables with normal distributions, the following parametric tests were used: the t test for independent samples and the paired t test. For variables with non-normal distributions, the nonparametric Mann-Whitney $\mathrm{U}$ test and the Wilcoxon test were used. Values were considered significant when $p<0.05$.

\section{RESULTS}

Table 1 presents the assessed health and motor performance indicators according to the group with the TT genotype, the allele not associated with obesity-risk, and the group with the AT/AA genotype, the allele (A) associated with obesity-risk. During the pre-test, the groups showed similar results and only differed with regard to agility. However, during the post-test, statistically significant differences were found between the groups: the individuals in the experimental group performed significantly more abdominal crunches, exhibited greater lower limb strength and produced faster times during speed tests $(p<0.05)$.

In the control group, genotype was not associated with statistically significant differences in any of the assessed indicators of physical fitness, health or motor performance. (Table 2) In the experimental group, after the intervention, individuals with the TT genotype showed significant improvements in abdominal strength $(p=0.025)$, lower limb strength $(p=0.037)$ and agility $(p=0.021)$. For individuals with the AA/AT genotype, improvements were found in flexibility $(p=0.026)$, abdominal strength ( $p=0.002)$, upper limb strength ( $p=0.008$ ) and lower limb strength $(p=0.001)$. However, these improvements were not statistically significant when comparing genotypes (TT versus AT/AA).

Table 2. Physical fitness indicators related to health and motor performance after four-month intervention according to rs9939609 polymorphism genotypes.

\begin{tabular}{|c|c|c|c|c|c|}
\hline \multirow[b]{2}{*}{ Control group } & TT & \multirow{2}{*}{$\mathbf{p}^{1}$} & $\mathrm{AT} / \mathrm{AA}^{*}$ & \multirow{2}{*}{$p^{1}$} & \multirow{2}{*}{$p^{2}$} \\
\hline & $\mathrm{N}=9$ & & $\mathrm{~N}=8$ & & \\
\hline \multicolumn{6}{|l|}{ Health indicators } \\
\hline$\triangle C R F(\mathrm{~m})$ & $81.33(126.55)$ & 0.090 & $103.50(222.89)$ & 0.230 & 0.801 \\
\hline$\Delta$ Flexibility $(\mathrm{cm})$ & $3.27(5.08)$ & 0.089 & $-1.75(3.03)$ & 0.147 & 0.028 \\
\hline$\triangle$ Abdominal (rep) & $2(4)$ & 0.157 & $0(4)$ & 0.864 & 0.238 \\
\hline \multicolumn{6}{|l|}{ Motor performance } \\
\hline$\Delta \mathrm{MS}$ Strength $(\mathrm{m})$ & $0.20(0.38)$ & 0.149 & $0.12(0.25)$ & 0.199 & 0.648 \\
\hline$\Delta \mathrm{Ml}$ Strength $(\mathrm{m})$ & $0.05(0.07)$ & 0.060 & $0.03(0.11)$ & 0.417 & 0.652 \\
\hline$\Delta$ Agility (s) & $-0.32(0.34)$ & 0.021 & $-0.28(0.55)$ & 0.189 & 0.865 \\
\hline$\Delta$ Speed (s) & $-0.32(0.57)$ & 0.871 & $-0.37(0.36)$ & 0.778 & 0.982 \\
\hline Experimental group & $N=6$ & $p^{1}$ & $\mathrm{~N}=13$ & $p^{1}$ & $p^{2}$ \\
\hline \multicolumn{6}{|l|}{ Health indicators } \\
\hline$\Delta C R F(m)$ & $-20.50(14.19)$ & 0.678 & $35.53(210.23)$ & 0.554 & 0.552 \\
\hline$\Delta$ Flexibility $(\mathrm{cm})$ & $1.41(5.08)$ & 0.525 & $4.38(6.22)$ & 0.026 & 0.323 \\
\hline$\triangle$ Abdominal (rep) & $7(6)$ & 0.025 & $5(4)$ & 0.002 & 0.319 \\
\hline \multicolumn{6}{|l|}{ Motor performance } \\
\hline$\Delta \mathrm{MS}$ Strength $(\mathrm{m})$ & $0.15(0.36)$ & 0.338 & $0.42(0.48)$ & 0.008 & 0.246 \\
\hline$\Delta \mathrm{Ml}$ Strength $(\mathrm{m})$ & $0.17(0.15)$ & 0.037 & $0.18(0.13)$ & 0.001 & 0.914 \\
\hline$\Delta$ Agility $(s)$ & $-1.13(0.70)$ & 0.010 & $-1.53(0.38)$ & $0.001^{5}$ & 0.161 \\
\hline$\Delta$ Speed (s) & $0.26(0.40)$ & 0.164 & $0.15(0.33)$ & 0.126 & 0.510 \\
\hline
\end{tabular}

CRF: cardiorespiratory fitness; MS: upper limbs; MI: lower limbs; rep: repeat; $\Delta$ : difference after the intervention; All data are expressed as the mean (standard deviation). p1: paired t test or \$Wilcoxon; p2: $t$ test for independent samples or ¥Mann-Whitney $U$ test.

Table 1. Physical fitness indicators related to health and motor performance before and after four months of the intervention, stratified based on rs9939609 polymorphism genotypes.

\begin{tabular}{|c|c|c|c|c|c|c|}
\hline \multirow[b]{2}{*}{ FTO rs9939609 genotype } & \multicolumn{2}{|c|}{ Before intervention } & \multirow[b]{2}{*}{$\mathrm{p}$} & \multicolumn{2}{|c|}{ After four-month intervention } & \multirow[b]{2}{*}{$\mathrm{p}$} \\
\hline & $\begin{array}{l}\text { Control } \\
\text { group }\end{array}$ & Experimental group & & $\begin{array}{l}\text { Control } \\
\text { group }\end{array}$ & Experimental group & \\
\hline TT & $\mathrm{N}=9$ & $\mathrm{~N}=6$ & & $\mathrm{~N}=9$ & $\mathrm{~N}=6$ & \\
\hline \multicolumn{7}{|l|}{ Health indicators } \\
\hline CRF (m) & $680.33(37.96)$ & $885.33(234.57)$ & 0.085 & $761.67(122.74)$ & $864.83(250.08)$ & 0.381 \\
\hline Flexibility $(\mathrm{cm})$ & $15.11(7.16)$ & $21.33(9.74)$ & 0.176 & $18.38(6.88)$ & $22.75(7.31)$ & 0.262 \\
\hline \multicolumn{7}{|l|}{ Motor performance } \\
\hline MS Strength $(\mathrm{m})$ & $2.94(0.42)$ & $3.11(0.59)$ & 0.535 & $3.15(0.47)$ & $3.27(0.61)$ & 0.674 \\
\hline Ml Strength $(\mathrm{m})$ & $1.06(0.10)$ & $1.19(0.17)$ & 0.084 & $1.11(0.15)$ & $1.36(0.19)$ & 0.015 \\
\hline Agility (s) & $7.68(0.76)$ & $8.01(0.45)$ & 0.363 & $7.35(0.76)$ & $6.88(0.59)$ & 0.221 \\
\hline Speed (s) & $5.06(0.66)$ & $4.97(0.37)$ & 0.770 & $5.03(0.50)$ & $5.24(0.36)$ & 0.394 \\
\hline Abdominal (rep) & $23(7)$ & $18(8)$ & 0.151 & $23(8)$ & $23(10)$ & 0.983 \\
\hline \multicolumn{7}{|l|}{ Motor performance } \\
\hline MS Strength (m) & $3.55(1.10)$ & $2.95(0.72)$ & 0.150 & $3.68(1.10)$ & $3.38(0.80)$ & 0.484 \\
\hline Ml Strength (m) & $1.28(0.27)$ & $1.12(0.17)$ & 0.138 & $1.31(0.24)$ & $1.31(0.20)$ & 0.960 \\
\hline Agility (s) & $7.22(0.76)$ & $8.25(0.64)$ & $0.005^{\S}$ & $6.94(0.78)$ & $6.72(0.69)$ & 0.507 \\
\hline Speed (s) & $4.77(0.30)$ & $5.11(0.51)$ & 0.074 & $4.73(0.38)$ & $5.26(0.59)$ & 0.039 \\
\hline
\end{tabular}

CRF: cardiorespiratory fitness; MS: upper limbs; MI: lower limbs; rep: repeat; $t$ test for independent samples; $\$$ Mann-Whitney U test; *A allele: obesity risk. 


\section{DISCUSSION}

The current study aimed to determine whether individuals who possess rs9939609 FTO gene polymorphism genotypes associated with obesity risk (AA and AT) would respond differently to a physical exercise intervention than individuals who possess a genotype (TT) that is not associated with obesity risk. To make this determination, the results of physical fitness tests related to health and motor performance were compared. We hypothesized that carriers of the obesity-risk allele (A) would exhibit inferior performance on tests of physical fitness, health and motor performance. Unexpectedly, we found that individuals with different genotypes had similar test performance. After the intervention period, we observed increases in abdominal strength, lower limb strength and agility in all individuals (genotypes TT, AT and AA).

Similar results were found by Milanezi, ${ }^{20}$ who conducted a study on 96 students in São Paulo. In the referenced study, students who attended physical education classes for 34 weeks showed significant improvements in abdominal strength, aerobic endurance and flexibility. The Milanezi study data are concordant with our results regarding physical fitness and health. Another study conducted on 40 high school students in São Paulo found significant changes in abdominal strength and flexibility in both sexes and improved aerobic endurance in girls following the attendance of physical education classes. ${ }^{21}$

In a study published by Ortega et al., ${ }^{22}$ the physical fitness levels of 3,528 teenagers from southern and north central Europe were evaluated. It was found that adolescents from southern Europe performed worse on physical fitness tests (strength, agility, speed and cardiorespiratory fitness) compared to adolescents from north central Europe ( $p<0.001)$. The adolescents from southern Europe were less active, which may explain the observed differences in speed, agility and cardiorespiratory fitness; these results were not related to the rs9939609 FTO gene polymorphism.
While many intervention programs conducted on overweight and obese children and adolescents have analyzed indicators of engine performance and health, few have assessed physical activity in relation to specific genotypes. $3,23,24$

Because our study sample cannot be considered as representative of the population, the strength of our identified association between the rs9939609 FTO gene polymorphism and indicators of physical fitness, health and motor performance is limited. Furthermore, a previous study reported by Liu et al. ${ }^{3}$ that was conducted in Georgia (USA) found no statistically significant associations between the rs9939609 FTO gene polymorphism and physical activity in a cross-sectional analysis of 1,978 young people.

Similar results were found in a study reported by Eynon et al.. ${ }^{25}$ In this study, a total of 551 Caucasian subjects of European descent (Poland, Russia and Spain) were evaluated. At the end of the study, no association between FTO gene polymorphism and the physical performance of athletes was found.

Thus, the results of the above-referenced studies corroborate the findings of our study. We could not find any previously published intervention studies that evaluated physical fitness, health and motor performance in relation to the rs9939609 FTO gene polymorphism. We also could not find any studies that compared the TT genotype with the AT/AA genotypes.

\section{CONCLUSIONS}

In conclusion, following an interdisciplinary exercise intervention, individuals with different genotypes (AA, AT and TT) for the rs9939609 FTO gene polymorphism exhibit similar levels of physical fitness, health and motor performance. Additionally, there were significant post-intervention improvements in abdominal strength, lower limb strength and agility in individuals of all genotypes (TT/AT/AA) in the experimental group.

All authors declare no potential conflict of interest related to this article.

AUTHORS' CONTRIBUTIONS: Each author made significant individual contributions to this manuscript. GGM (0000-0003-1794-1176)* and CPR (0000-0002-4549-3959)* were responsible for the genetic analyses, and were also the main contributors to the drafting of the manuscript. ElK (0000-0001-7474-7471)* was responsible for the genetic analyses. ARMV (0000-0001-9611-3103)* was responsible for the genetic analyses and for writing the manuscript. DP (0000-0003-2818-0173)* helped with the statistical analysis and writing of the manuscript. MSB (0000-0001-7120-1887)* designed the study and supervised the data collection and approval of the final version of the manuscript. All authors read and approved the final manuscript. *ORCID (Open Researcher and Contributor ID).

\section{REFERENCES}

1. Flegal KM, Graubard BI, Williamson DF, Gail MH. Cause-specific excess deaths associated with underweight, overweight, and obesity. JAMA. 2007;298 (17):2028-37.

2. LuczynskiW, Zalewski G, Bossowski A. The association of the FTO rs9939609 polymorphism with obesity and metabolic risk factors for cardiovascular diseases in Polish children. J Physiol Pharmacol. 2012;63:241-8.

3. Liu G, Zhu H, Lagou V, Gutin B, Stallmann-Jorgensen IS, Treiber FA, et al. FTO variant rs9939609 is associated with body mass index and waist circumference, but not with energy intake or physical activity in European- and African-American youth. BMC Med Genet. 2010;9:11-57.

4. Demerath EW, Lutsey PL, Monda KL, Linda-Kao WH, Bressler J, Pankow JS, et al. Interaction of FTO and physical activity level on adiposity in african-american and european american adults: the ARIC study. Obesity (Silver Spring). 2011;19(9):1866-72.

5. Gerken T, Girard CA, Tung Y-C, Webby CJ, Saudek V, Hewitson KS, et al. The obesity-associated FTO gene encodes a 2-oxoglutarate-dependent nucleic acid demethylase. Science. 2007;318:1469-72.

6. Dina C, Meyre D, Gallina S, Durand E, Körner A, Jacobson P, et al. Variation in FTO contributes to childhood obesity and severe adult obesity. Nat Genet. 2007;39:724-6.

7. Vujovic P, Stamenkovic S, Jasnic N, Lakic I, Djurasevic SF, Cvijic G, et al. Fasting induced cytoplasmic FTO expression in some neurons of rat hypothalamus. PLoS One. 2013;8:(5)1-6.

8. Tung YL, Ayuso E, Shan X, Bosch F, O'Rahilly S, Coll AP, et al. Hypothalamic-specific manipulation of FTO, the ortholog of the human obesity gene FTO, affects food intake in rats. PLoS One. 2010;5:e8771.

9. Mitchell JA, Church TS, Rankinen T, Earnest CP, Sui X, Blair SN. FTO genotype and the weight loss benefits of moderate intensity exercise. Obesity (Silver Spring). 2010;18:641-3.

10. Ortega FB, Ruiz JR, Castillo MJ, Sjöström M. Physical fitness in childhood and adolescence: a powerful marker of health. Int J Obes (Lond). 2008:32:1-11.

11. Ruiz JR, Castro-Piñero J, Artero EG, Ortega FB, Sjöström M, Suni J et al. Predictive validity of health-related fitness in youth: a systematic review. Br J Sports Med. 2009;43:909-23.

12. Olds T, Tomkinson G, Léger L, Cazorla G. Worldwide variation in the performance of children and adolescents: an analysis of 109 studies of the 20-m shuttle run test in 37 countries. J Sports Sci. 2006;24:1025-38

13. Malina RM, Katzmarzyk PT. Physical activity and fitness in an international growth standard for preadolescent and adolescent children. Food Nutr Bull. 2006;27:S295-313.
14. Bovet P, Auguste R, Burdette H. Strong inverse association between physical fitness and overweight in adolescents: a large school-based survey. Int J Behav Nutr Phys Act. 2007;4:24.

15. Gouveia ER, Freitas DL, Maia JA, Beunen GP, Claessens AL, Marques AT, et al. Physical activity, fitness and overweight in children and adolescents: the Madeira Growth Study. Rev Bras Educ Fís Esp. 2007;21(2):95-106.

16. Faul F, Erdfelder E, Lang AG, Buchner A. G*Power 3: a flexible statistical power analysis program for the social, behavioral, and biomedical sciences. Behav Res Methods. 2007;39(2):175-91.

17. Miller SA, Dykes DD, Polesky HF. A simple salting out procedure for extracting DNA from human nucleated cells. Nucleic Acids Res. 1988;16(3):1215.

18. Centers for Disease Control and Prevention. National Center for Health Statistics. CDC Growth Charts: United States. 2000. [accesso em 2014 dez 23].Disponivel em: http://www.cdc.gov/growthcharts.

19. Gaya A, Lemos A, Gaya A, Teixeira D, Pinheiro E, Moreira R. PROESP - Sports Brazil project: manual. 2012 [accesso em 2014 nov 19]. Disponível em: http://www.proesp.ufrgs.br/arquivos/Manual-PROESP-BR-2012.pdf.

20. Milanezi JZ. Atividade física para saúde no ensino médio e no tempo livre: estudo quase-experimenta em Bauru, SP [Dissertação de Mestrado]. Campinas (SP): Faculdade de Educação Física, Unicamp; 2001.

21. Cardoso MA, Pereira FM, Afonso MdR, Rocha Junior IC. Physical education in middle school: development of concepts and health-related physical fitness. Rev Bras Educ Fís Esp. 2014;28:147-61.

22. Ortega FB, Ruiz JR, Labayen I, Martínez-Gómez D, Vicente-Rodriguez G, Cuenca-García M, et al. Health inequalities in urban adolescents: role of physical activity, diet, and genetics. Pediatrics 2014;133(4):e884-95.

23. Vimaleswaran KS, Li S, Zhao JH, Luan J, Bingham SA, Khaw KT, et al. Physical activity attenuates the body mass index-increasing influence of genetic variation in the FTO gene. Am J Clin Nutr 2009;90(2):425-8

24. Xi B, Wang C, Wu L, Zhang M, Shen Y, Zhao X et al. Influence of physical inactivity on associations between single nucleotide polymorphisms and genetic predisposition to childhood obesity. Am J Epidemiol 2011;173:1256-62.

25. Eynon N, Nasibulina ES, Banting LK, Cieszczyk P, Maciejewska-Karlowska A, Sawczuk M, et al. The FTO A/T polymorphism and elite athletic performance: a study involving three groups of European athletes. PLoS One. 2013;8(4):e60570. 